\section{(A) Check for updates}

Cite this: Dalton Trans., 2021, 50 4345

Received 27th January 2021 Accepted 2nd March 2021

DOI: $10.1039 / \mathrm{d} 1 \mathrm{dt} 00287 \mathrm{~b}$ rsc.li/dalton

\title{
Ethylene oligomerisation chromium catalysts with unsymmetrical PCNP ligands $\uparrow$
}

\author{
Kevin Blann, ${ }^{a}$ Annette Bollmann, ${ }^{a}$ Gavin M. Brown, ${ }^{b}$ John T. Dixon, ${ }^{a}$

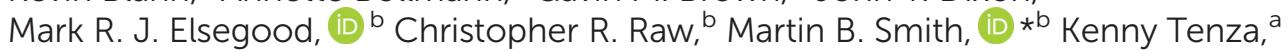 \\ J. Alexander Willemse ${ }^{a}$ and Pumza Zweni ${ }^{a}$
}

\begin{abstract}
Chromium(III) complexes of chelating diphosphines, with PNP or PCNCP backbones, are excellent catalysts for ethylene tetra- and/or trimerisations. A missing link within this ligand series are unsymmetric chelating diphosphines based on a PCNP scaffold. New bidentate PCNP ligands of the type $\mathrm{Ph}_{2} P C \mathrm{H}_{2} \mathrm{~N}(\mathrm{R})$ $\mathrm{PPh}_{2}(\mathrm{R}=1$-naphthyl or 5-quinoline groups, $\mathbf{2 a}-\mathbf{d}$ ) have been synthesised and shown to be extremely effective ligands for ethylene tri-/tetramerisations. Three representative tetracarbonyl $\mathrm{Cr}^{0}$ complexes bearing a single $\mathrm{PN}(\mathrm{R}) \mathrm{P}(5), \mathrm{PCN}(\mathrm{R}) \mathrm{P}(\mathbf{6})$, or $\mathrm{PCN}(\mathrm{R}) \mathrm{CP}(7)$ diphosphine ( $\mathrm{R}=1$-naphthyl) have been prepared from $\mathrm{Cr}(\mathrm{CO})_{4}\left(\eta^{4}-\mathrm{nbd}\right)$ (nbd = norbornadiene). Furthermore we report a single crystal X-ray diffraction study of these compounds and discuss their structural parameters.
\end{abstract}

\section{Introduction}

There has been considerable interest in developing new homogeneous catalysts for selective ethylene oligomerisations affording, with high selectivity, linear alkenes such as 1-hexene or 1-octene. ${ }^{1}$ This is largely due to the increase in demands for commercial products based on polyethylene. Small bite angle ligands, based on a bidentate $\mathrm{P}-\mathrm{N}-\mathrm{P}$ scaffold, have previously been shown to be excellent ligands, in conjunction with simple $\mathrm{Cr}^{\mathrm{III}}$ salts, for either selective ethylene trimerisation or tetramerisation. ${ }^{2-7}$ Crucially, such selectivity originates from careful tuning of the $-\mathrm{PR}_{2}$ or $-\mathrm{NR}$ substituents of the PNP ligands ${ }^{2-7}$ with the $\left(\mathrm{Ph}_{2} \mathrm{P}\right)_{2} \mathrm{~N}^{\mathrm{i}} \mathrm{Pr}$ ligand being the exemplar for ethylene tetramerisation (Chart 1$){ }^{4}$

Expanding the ligand scope to include methylene spacers in the bidentate PNP backbone has been shown to increase the ligand bite angle around the $\mathrm{Cr}$ metal centre., Furthermore, Le Floch and co-workers were able to switch triand tetramerisation behaviour by R group manipulation of the phosphine groups of PCNCP-type ligands. ${ }^{10}$ Inspired by these findings, chemists have sought to explore the scope of Group 15/16 ligands for Cr-catalysed ethylene oligomerisations ${ }^{11,12}$ and polymerisations. ${ }^{13}$ Some examples of P-based ligands studied, for ethylene tri-/tetramerisations, highlight the vari-

${ }^{a} R \&$ D Division, Sasol Technology (Pty) Ltd., 1 Klasie Havenga Road, Sasolburg, South Africa

${ }^{b}$ Department of Chemistry, Loughborough University, Loughborough, Leics, LE11 3TU, UK. E-mail: m.b.smith@lboro.ac.uk

$\dagger$ CCDC 2018019-2018022. For crystallographic data in CIF or other electronic format see DOI: $10.1039 / \mathrm{d} 1 \mathrm{dt} 00287 \mathrm{~b}$

ation of backbone groups including $-\mathrm{NN}-{ }^{14,15}-\mathrm{CC}^{16,17}$ and -NSi- (shown in Chart 1). ${ }^{18}$

Whilst significant advances in ligand design have aided catalyst performance, there have also been considerable computational $^{19-22}$ and mechanistic ${ }^{23-25}$ efforts to probe the nature of catalytically important Cr-based intermediates, and the origin of 1-hexene and 1-octene selectivities. As part of our studies regarding the synthesis of PNP and PCNCP ligands ${ }^{26,27}$ we explored a missing counterpart to these two classes, namely PCNP bidentate ligands bearing two electronically different trivalent phosphorus centres. We report here the synthesis of such PCNP ligands and their potential as $\mathrm{Cr}^{\mathrm{III}}$ based catalysts for ethylene tri-/tetramerisations. To understand the impact of ligand effects on catalyst activity/selectivity

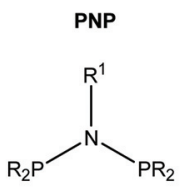

Extensively studied
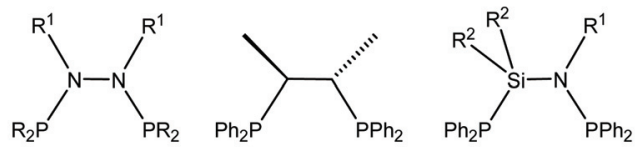

Some previously studied 1,2 diphosphines

Chart 1 Recent examples of ligands studied for $\mathrm{Cr}$-catalysed ethylene tri-/tetramerisations. 
we also prepared three simple $\mathrm{Cr}^{0}$ complexes $\mathrm{Cr}(\mathrm{CO})_{4}\{\mathrm{PN}(\mathrm{R}) \mathrm{P}\}$, $\mathrm{Cr}(\mathrm{CO})_{4}\{\mathrm{PCN}(\mathrm{R}) \mathrm{P}\}$ and $\mathrm{Cr}(\mathrm{CO})_{4}\{\mathrm{PCN}(\mathrm{R}) \mathrm{CP}\}[\mathrm{R}=1$-Naphthyl $]$ and investigated their $\mathrm{X}$-ray structures. We have attempted to correlate $\mathrm{Cr}-\mathrm{P}$ bond lengths and $\mathrm{P}-\mathrm{Cr}-\mathrm{P}$ ligand bite angles with catalytic activity in order to gain further insight into the structure catalyst selectivity/activity relationships. ${ }^{21}$

\section{Results and discussion}

For the synthesis of unsymmetrical $\mathrm{P}-\mathrm{C}-\mathrm{N}-\mathrm{P}$ chelating ligands ${ }^{28}$ we targeted two plausible routes to their preparation (Scheme 1). Both pathways rely on condensation reactions, with elimination of $\mathrm{HCl}\left(\mathrm{P}-\mathrm{N}\right.$ bond formation) or $\mathrm{H}_{2} \mathrm{O}\left(\mathrm{P}-\mathrm{CH}_{2}\right.$ bond formation), the sequence of which varies, depending on the route chosen. Each initial step involves a single substitution only and it is therefore necessary to prevent double substitution, for example PCNCP formation, ${ }^{29}$ which can result, depending on the primary amine source.

\section{Monodentate aminomethylphosphines}

Our initial starting point for this work was the realisation that $\mathrm{R}_{2} \mathrm{PN}\left(\mathrm{R}^{1}\right) \mathrm{PR}_{2}$ and $\mathrm{R}_{2}^{2} \mathrm{PCN}\left(\mathrm{R}^{1}\right) \mathrm{CPR}^{2}{ }_{2}\left(\mathrm{R}^{1}={ }^{\mathrm{i}} \mathrm{Pr}\right)$ have been shown to be excellent ligands, in conjunction with $\mathrm{Cr}^{\mathrm{III}}$ salts, for ethylene tetramerisation and trimerisations. ${ }^{2,10}$ Accordingly, we began our studies using isopropylamine, with the attempted syntheses of (i) $\mathrm{Ph}_{2} \mathrm{PCH}_{2} \mathrm{NH}^{\mathrm{i}} \mathrm{Pr}$ and (ii) the reaction of $\mathrm{Ph}_{2} \mathrm{PNH}^{\mathrm{i}} \mathrm{Pr}$ with $\mathrm{Ph}_{2} \mathrm{PCH}_{2} \mathrm{OH}$. In our hands, both routes were somewhat problematic. During the preparation of $\mathrm{Ph}_{2} \mathrm{PCH}_{2} \mathrm{NH}^{\mathrm{i}} \mathrm{Pr}$ we often observed large amounts of $\left(\mathrm{Ph}_{2} \mathrm{PCH}_{2}\right)_{2} \mathrm{~N}^{\mathrm{i}} \mathrm{Pr}\left(>35 \%\right.$ as judged by ${ }^{31} \mathrm{P}\left\{{ }^{1} \mathrm{H}\right\}$ NMR). The condensation of $\mathrm{Ph}_{2} \mathrm{PNH}^{\mathrm{i}} \mathrm{Pr}$ with $\mathrm{Ph}_{2} \mathrm{PCH}_{2} \mathrm{OH}$ often resulted in formation of various unidentified phosphorus products, reflecting the instability of the $\mathrm{P}-\mathrm{N}$ bond with this phosphinoamine under these conditions. In order to circumvent this, we substituted the more basic ${ }^{\mathrm{i}} \mathrm{PrNH}_{2}$ for 1-naphthylamine (and two substituted analogues) or 5-aminoquinoline and this enabled the synthesis of the secondary amines 1a-d (61-82\% isolated yields) to be achieved from $\mathrm{Ph}_{2} \mathrm{PCH}_{2} \mathrm{OH}$ in $\mathrm{MeOH}$ (Scheme 2). The spectroscopic and analytical data are in agreement with

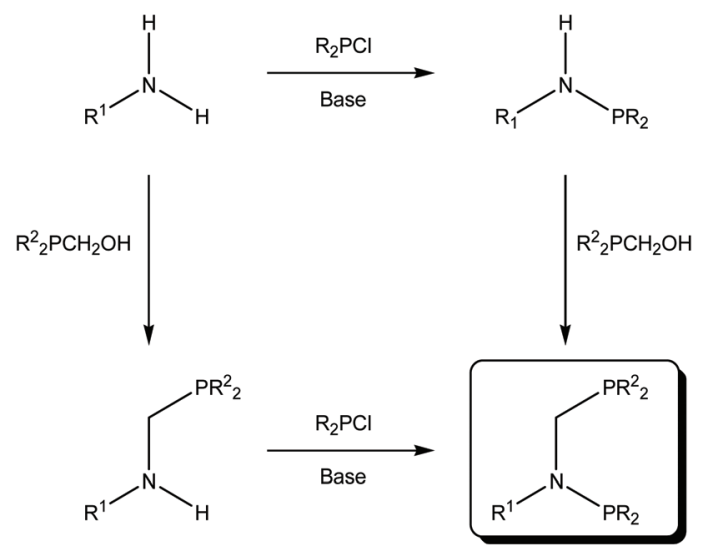

Scheme 1 Generalised synthetic pathways to PCNP ligands. the expected structures confirming only single substitution had resulted. Hence one resonance in the ${ }^{31} \mathrm{P}\left\{{ }^{1} \mathrm{H}\right\}$ NMR spectra for 1a-d at $c a . \delta-19 \mathrm{ppm}$ is observed with respect to $\mathrm{Ph}_{2} \mathrm{PCH}_{2} \mathrm{OH}\left[\delta-10.0 \mathrm{ppm}, \mathrm{CDCl}_{3}\right]$. In the ${ }^{1} \mathrm{H}$ NMR spectra, a broad $\mathrm{NH}$ resonance was observed in the region of $\delta 3.7-4.5 \mathrm{ppm}$ with the weakly absorbing $\nu(\mathrm{NH})$ vibration at approx. $3300 \mathrm{~cm}^{-1}$ further confirming single $\mathrm{P}-\mathrm{C}$ bond formation leaving a free $\mathrm{NH}$ site for further functionalisation. The X-ray structure (Fig. 1) of 1a has been determined.

\section{Unsymmetrical bidentate aminomethylphosphines}

With precursors 1a-d in hand, deprotonation with a slight excess of LDA, followed by quenching with $\mathrm{Ph}_{2} \mathrm{PCl}$ and workup, gave the bidentate ligands $2 \mathbf{a}-\mathbf{d}$ in $41-77 \%$ isolated yields (Scheme 2). Ligands $\mathbf{2 a - d}$ prepared by this route were found to be air stable both in the solid state and in solution. No reaction occurred between $\mathbf{1 a}-\mathbf{d}, \mathrm{Ph}_{2} \mathrm{PCl}$ and either $\mathrm{NEt}_{3}$ (or ${ }^{n} \mathrm{BuLi}$ ) following common $\mathrm{P}-\mathrm{N}$ methodologies used for accessing PNP ligands. ${ }^{9,27,30,31}$

Ligands 2a-d exhibited classic AX patterns in their respective ${ }^{31} \mathrm{P}\left\{{ }^{1} \mathrm{H}\right\}$ NMR spectra due to the inequivalent $\mathrm{P}$ nuclei in these compounds. The chemical shifts of these doublets in 2a-d were all very similar and at approx. $\delta-21\left(\mathrm{PCH}_{2}\right)$ and $\delta 68$ (PN) $\mathrm{ppm}^{10,14}$ indicating that small changes in the $\mathrm{R}^{1}$ aromatic substituent have negligible effect on the electronic properties of the $\mathrm{P}$ nuclei. The absence of an $\mathrm{NH}$ resonance in the ${ }^{1} \mathrm{H}$ NMR spectra and of a $\nu(\mathrm{NH})$ stretch in the IR spectra confirmed that the amine group has successfully been replaced by $\mathrm{a}-\mathrm{PPh}_{2}$ group.

\section{Chromium(0) tetracarbonyl complexes of $2 \mathrm{a}, 3$, and 4}

The unsymmetrical bidentate ligands $\mathbf{2 a - d}$, in addition to the known PNP $(3)^{30}$ and PCNCP (4) ligands of 1-naphthylamine prepared by reaction with 2 equiv. of either $\mathrm{Ph}_{2} \mathrm{PCl}$ or $\mathrm{Ph}_{2} \mathrm{PCH}_{2} \mathrm{OH}$ respectively, have been evaluated for Cr-catalysed ethylene oligomerisation (vide infra). It was therefore useful to briefly ascertain their coordination behaviour and how these ligands react with $\mathrm{Cr}^{\mathrm{III}}$. We focused our efforts on the reactivity of $2 \mathrm{a}, 3$, and 4 towards $\mathrm{Cr}(\mathrm{CO})_{4}\left(\eta^{4}-\mathrm{nbd}\right)$ in THF which gave the corresponding octahedral complexes $5-7$ in $56-70 \%$ isolated

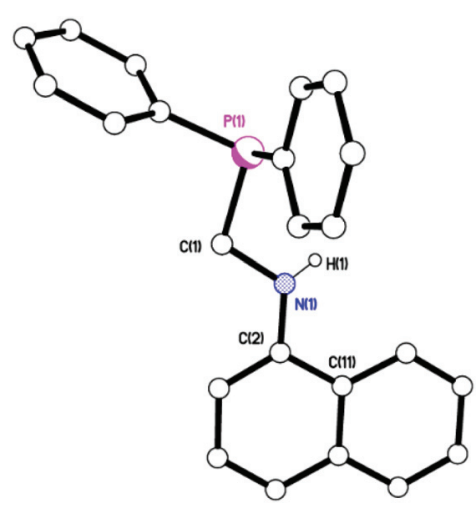

Fig. 1 Molecular structure of $\mathrm{Ph}_{2} \mathrm{PCH}_{2}\{1-\mathrm{N}(\mathrm{H}) \mathrm{Nap}\}$ (1a). All hydrogen atoms except on $\mathrm{N}(1)$ have been omitted for clarity. 
<smiles>[X]c1ccc(NN)c2cccnc12</smiles><smiles>[X]c1ccc(NCc2ccccc2)c2cccnc12</smiles>

1a $\mathrm{X}=\mathrm{H}, \mathrm{Y}=\mathrm{CH}$ 1b $X=\mathrm{Cl}, \mathrm{Y}=\mathrm{CH}$ 1c $\mathrm{X}=\mathrm{Br}, \mathrm{Y}=\mathrm{CH}$

1d $X=H, Y=N$

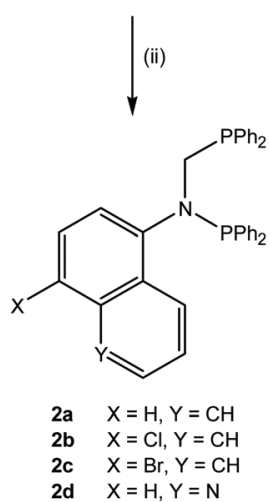
complexes with these ligand classes. ${ }^{3 a, 4,5 a, 15,31}$
Scheme 2 Reagents and conditions: (i) $\mathrm{Ph}_{2} \mathrm{PCH}_{2} \mathrm{OH}, \mathrm{MeOH}$; (ii) $\mathrm{LDA}$, $-78^{\circ} \mathrm{C}, \mathrm{Ph}_{2} \mathrm{PCl}$.

yields as pale yellow solids (Chart 2). The ${ }^{31} \mathrm{P}\left\{{ }^{1} \mathrm{H}\right\}$ NMR spectra were in good agreement with structures based on coordinated symmetrical PNP $(5, \delta 117.5 \mathrm{ppm})$ and PCNCP $(7, \delta 41.0 \mathrm{ppm})$ ligands along with an $\mathrm{AX}$ spectrum for the unsymmetrical fivemembered PCNP chelate complex $6\left[\delta 67.9\left(\mathrm{PCH}_{2}\right), 142.8(\mathrm{PN})\right.$, $\left.J_{\mathrm{PP}}=32 \mathrm{~Hz}\right]$. Furthermore the FT-IR spectra of 5-7 reveal ligands $\mathbf{2 a}, \mathbf{3}$, and $\mathbf{4}$ have very similar electronic properties, the $\nu(\mathrm{CO})$ values for 5 and $\mathbf{6}$ being similar to previously reported

The geometries of $5, \mathbf{6}$, and $7 \cdot \mathrm{CH}_{2} \mathrm{Cl}_{2}$ are essentially octahedral with respect to the $\mathrm{Cr}^{0}$ centre and the $\mathrm{P}$ donor atoms are in a cis arrangement affording four, five, or six-membered chelate rings respectively (Fig. 2). The major features of these<smiles></smiles><smiles>[R]N1CPC(C(=O)[O-])(C(=O)[O-])P(c2ccccc2)P1</smiles>

5<smiles>[R]N1CPC(=O)C([O-])([O-])P(C(=O)[O-])C1</smiles>

7

$(\mathrm{R}=1-\mathrm{Nap})$

Chart 2 Structures of complexes 5, 6, and 7. structures are very similar and are also comparable with known $\mathrm{Cr}^{0}$ complexes bearing $\mathrm{PNP}^{32}$ or PNNP ligands. ${ }^{15}$ For complexes 5, 6, and 7. $\mathrm{CH}_{2} \mathrm{Cl}_{2}$, the $\operatorname{Cr}(1)-\mathrm{P}(1)$ and $\operatorname{Cr}(1)-\mathrm{P}(2)$ bond lengths are similar, despite the different electronic properties of the two $-\mathrm{PPh}_{2}$ groups imposed by the additional one or two methylene groups. As expected, for the $\mathrm{Cr}^{0}$ complexes there is an increase in $\mathrm{P}-\mathrm{M}-\mathrm{P}$ bite angle and $\mathrm{M} \cdots \mathrm{N}$ distance on progressing the series from $5>\mathbf{6}>\mathbf{7} \cdot \mathrm{CH}_{2} \mathrm{Cl}_{2}$, reflecting an increase in chelate ring size (Table 1). The 4-membered chelate ring of $\mathbf{5}$ is not quite planar as shown by an angle of 164.46(6) ${ }^{\circ}$ between the $\mathrm{Cr}(1)-\mathrm{P}(1)-\mathrm{P}(2)$ and $\mathrm{P}(1)-\mathrm{P}(2)-\mathrm{N}(1)$ planes. Compound $7 \cdot \mathrm{CH}_{2} \mathrm{Cl}_{2}$ adopts a pseudo-chair conformation with $\operatorname{Cr}(1) \quad 0.9480(9) \AA$ above and $\mathrm{N}(1) 0.7380(14) \AA$ below the $\mathrm{P}(1)-\mathrm{P}(2)-\mathrm{C}(6)-\mathrm{C}(5)$ plane. The $\mathrm{Cr}$ complex 6 sits in a twisted envelope conformation with both $\mathrm{N}(1)$ and $\mathrm{C}(5)$ above the plane containing $\operatorname{Cr}(1)-\mathrm{P}(1)-\mathrm{P}(2)$ by $0.4501(14) \AA$ and $0.9328(16) \AA$ respectively. Moreover there is an observed difference in the angle at which the 1-naphthyl substituent resides with respect to the chelate rings for these three $\mathrm{Cr}^{0}$ complexes. The torsion angle decreases from $77.612(16)^{\circ}(5)$ to $55.74(3)^{\circ}$ $\left(7 \cdot \mathrm{CH}_{2} \mathrm{Cl}_{2}\right)$ on going from the 4 -membered to 6 -membered chelate rings, whereas 6 displays larger, almost perpendicular, torsion angles of $88.85(5)$ and $86.90(5)^{\circ}$ for the two independent molecules. Finally N(1) in $\mathbf{5}$ (sum of angles $=360^{\circ}$ ) and $\mathbf{6}$ (sum of angles for both molecules $=358^{\circ}$ ) is essentially planar, consistent with nitrogen lone pair delocalisation over the four/ five-membered chelates, whereas in 7 the nitrogen atom is pyramidal (sum of angles $=338^{\circ}$ ).

\section{Oligomerisation results and discussion}

Despite the mentioned synthetic challenges and the labile nature of the bidentate PCNP diphosphines during purification, four $N$-naphthyl variants of the PCNP systems (2a-d) with their corresponding $\mathrm{PCN}(\mathrm{H})$ - "half molecules" (1a-d) were successfully synthesised which enabled their evaluation as ligands under ethylene oligomerisation conditions. A few substituents were thus introduced onto the naphthylene moiety to effect variation in the electronic properties of these prospective oligomerisation ligands. Ligands $\mathbf{1 b} / \mathbf{2 b}$ and $\mathbf{1 c} / \mathbf{2 c}$ were synthesised to explore the impact of the electron withdrawing chloro and bromo groups onto the amino naphthylene backbone whereas the quinoline analogues (1d/2d) contains heteroaromatic functionality.

Mixtures of the $\mathrm{Ph}_{2} \mathrm{PCH}_{2} \mathrm{~N}(\mathrm{R}) \mathrm{H}$ ligands (1a-d) and $\mathrm{Cr}^{\mathrm{III}}$ salt in solution were activated with MMAO-3A and screened for ethylene oligomerisation using typical tri- and tetramerisation conditions. Albeit at comparatively low catalyst activities, these systems were all active for ethylene oligomerisation upon MMAO activation (see Table 2). Selectivity towards both 1-hexene and 1-octene were consistently low, resulting in a broad distribution in $\alpha$-olefins and consistent high yields of $\mathrm{C}_{10-14}$ and $\mathrm{C}_{16+}$ olefin. In addition, polyethylene formation was high, at $70 \%$ of the total product generated, whilst catalyst activity obtained was only around 0.05 .

In contrast, the catalyst systems containing the corresponding $\mathrm{Ph}_{2} \mathrm{PCH}_{2} \mathrm{~N}(\mathrm{R}) \mathrm{PPh}_{2}$ ligands (2a-d) were all highly 

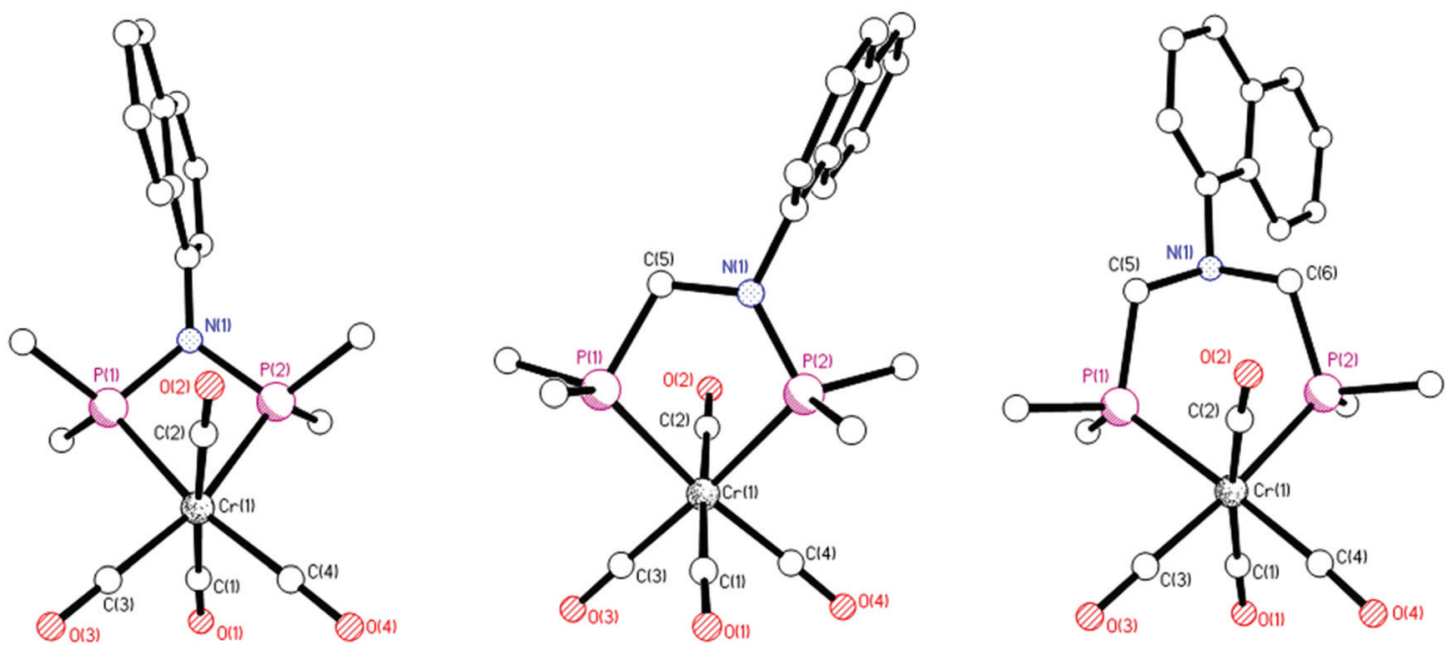

Fig. 2 Molecular structures of 5, 6, and 7. $\mathrm{CH}_{2} \mathrm{Cl}_{2}$ from left to right respectively. Only the ipso-Ph and naphthyl carbon atoms of the diphosphines are shown. All hydrogen atoms and solvent molecules of crystallisation have been omitted for clarity. One of two similar unique molecules of 6 shown.

Table 1 Selected bond lengths $(\AA \AA)$ and angles $\left(^{\circ}\right)$ for 5,6 and $7 \cdot \mathrm{CH}_{2} \mathrm{Cl}_{2}$

\begin{tabular}{llll}
\hline Compound & $\mathbf{5}$ & $\mathbf{6}^{a}$ & $\mathbf{7 \cdot \mathrm { CH } _ { 2 } \mathrm { Cl } _ { 2 }}$ \\
\hline $\mathrm{P}(1)-\mathrm{Cr}(1)-\mathrm{P}(2)$ & $68.787(11)$ & $81.322(16)$ & $87.144(14)$ \\
$\mathrm{Cr}(1)-\mathrm{P}(1)$ & $2.3445(3)$ & $2.3481(5)$ & $2.3637(4)$ \\
$\mathrm{Cr}(1)-\mathrm{P}(2)$ & $2.3447(3)$ & $2.3420(5)$ & $2.3567(4)$ \\
$\mathrm{Cr}(1) \cdots \mathrm{N}(1)$ & $3.0093(9)$ & $3.3195(3)$ & $3.9569(9)$ \\
$\sum$ around $\mathrm{N}(1)$ & 360 & 358 & 335
\end{tabular}

${ }^{a}$ Two molecules in the asymmetric unit. Values for the second unique molecule are very similar.

active and selective towards both 1-hexene and 1-octene formation, providing total $\alpha$-selectivities in excess of $82 \%$, as well as low polyethylene yields. The $\mathrm{Ph}_{2} \mathrm{PCH}_{2}\left\{1-\mathrm{N}\left(\mathrm{PPh}_{2}\right) \mathrm{Nap}\right\} / \mathrm{Cr} /$ MMAO catalyst system marginally outperformed the halogen containing and quinoline analogues, yielding a respectable total $\alpha$-selectivity of $87 \%$ and a $1-\mathrm{C}_{8}$ to $1-\mathrm{C}_{6}$ ratio of 1.23 .

These catalytic results indicate that the changes in the electronic and steric encumbrance properties of 2a to yield ligands 2b-d resulted in only a minor reduction in 1-octene selectivity. This is largely in line with observations of Killian et al. which demonstrated that electronic effects have little bearing on catalyst selectivity of $N$-aryl substituents for PNP/Cr tetramerisation catalyst systems. ${ }^{2 d}$ On the other hand, steric encumbrance or bulk substitution on PNP ligand systems in general favours 1-hexene formation over 1-octene, ${ }^{2 d, e}$ thus possibly explaining the lower 1-octene selectivities observed for the $\mathbf{2 a - d}$ based catalysts relative to that obtained using ligand $2 a$.

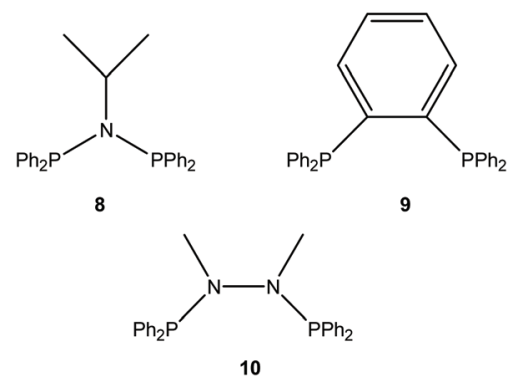

Table 2 Catalytic data for $1 \mathrm{a}-\mathrm{d}, 2 \mathrm{a}-\mathrm{d}$ and known (8-10) ligand systems

\begin{tabular}{|c|c|c|c|c|c|c|c|c|c|c|c|c|c|c|}
\hline & \multirow[b]{2}{*}{ Ligand } & \multicolumn{10}{|c|}{ Liquid product selectivity (wt \%) } & \multirow[b]{2}{*}{$1 \mathrm{C}_{8}: 1 \mathrm{C}_{6}$} & \multirow[b]{2}{*}{ Act. } & \multirow[b]{2}{*}{$\mathrm{PE}$} \\
\hline & & $\mathrm{C}_{6}$ & $1-\mathrm{C}_{6}$ & $1-\mathrm{C}_{6} / \mathrm{C}_{6}$ & $\mathrm{C}_{6}$ cyclics & $\mathrm{C}_{8}$ & $1-\mathrm{C}_{8}$ & $1-\mathrm{C}_{8} / \mathrm{C}_{8}$ & $\mathrm{C}_{10-14}$ & $\mathrm{C}_{16+}$ & Total $\alpha$ & & & \\
\hline 3 & $1 c^{b}$ & 16.7 & 13.8 & 82.6 & 1.50 & 22.0 & 17.7 & 80.5 & 21.3 & 38.5 & 31.5 & 1.29 & 0.052 & 69.2 \\
\hline 4 & $1 \mathbf{d}^{b}$ & 29.2 & 25.4 & 87.0 & 2.88 & 32.3 & 28.9 & 89.5 & 15.0 & 21.7 & 54.4 & 1.14 & 0.042 & 69.5 \\
\hline 5 & $2 a^{b}$ & 43.2 & 39.3 & 91.0 & 3.83 & 48.5 & 48.2 & 99.4 & 7.6 & 0.4 & 87.4 & 1.23 & 3.18 & 0.5 \\
\hline 8 & $2 d^{b}$ & 44.0 & 40.4 & 91.8 & - & 42.8 & 42.3 & 98.8 & - & - & 82.6 & 1.05 & 3.04 & 0.4 \\
\hline 9 & $8^{b}$ & 18.4 & 14.1 & 76.6 & 4.2 & 70.1 & 69.5 & 99.1 & 9.1 & 2.1 & 83.6 & 4.93 & 1.50 & 0.3 \\
\hline 10 & $\mathbf{9}^{b}$ & 27.3 & 14.2 & 52.0 & 12.2 & 56.5 & 54.6 & 96.6 & 9.1 & 4.8 & 68.8 & 3.85 & 1.59 & 0.2 \\
\hline 11 & $10^{b}$ & 30.4 & 25.1 & 82.6 & 5.2 & 62.8 & 62.4 & 99.4 & 6.0 & 0.5 & 87.5 & 2.48 & 1.41 & 1.4 \\
\hline
\end{tabular}

${ }^{a} 50$ bar, $60{ }^{\circ} \mathrm{C}, \mathrm{Cr}(\mathrm{acac})_{3} 5 \mu \mathrm{mol}$, MMAO-3A 480 eq., cyclohexane. ${ }^{b} 45$ bar, $60{ }^{\circ} \mathrm{C}, \mathrm{Cr}(\mathrm{acac})_{3} 2.5 \mu$ mol, MMAO-3A 960 eq., methylcyclohexane. Activity is given in ton product per $\mathrm{g}$ Cr per $\mathrm{h}$. 
Table 3 Effect of reaction pressure on catalyst activity and product selectivity (using 2a)

\begin{tabular}{|c|c|c|c|c|c|c|c|c|c|c|c|c|c|c|}
\hline $\mathrm{P}$ & {$\left[\mathrm{C}_{2} \mathrm{H}_{4}\right]\left(\mathrm{mol} \mathrm{L}^{-1}\right)$} & \multicolumn{10}{|c|}{ Liquid product selectivity (wt \%) } & $1 \mathrm{C}_{8}: 1 \mathrm{C}_{6}$ & Act. & PE \\
\hline 50 & 5.22 & 41.1 & 36.7 & 89.3 & 4.3 & 51.4 & 51.0 & 99.2 & 6.38 & 0.5 & 87.7 & 1.39 & 2.72 & 1.2 \\
\hline 80 & 8.09 & 39.6 & 35.3 & 89.1 & 4.3 & 54.2 & 53.7 & 99.1 & 4.64 & 0.6 & 89.0 & 1.52 & 2.35 & 0.9 \\
\hline
\end{tabular}

Conditions: $300 \mathrm{ml}$ Parr reactor, $2.5 \mu \mathrm{mol} \mathrm{Cr}(\mathrm{acac})_{3}$, MMAO-3A 960 eq., methylcyclohexane, $60^{\circ} \mathrm{C}$. Activity is given in ton product per g Cr per h.

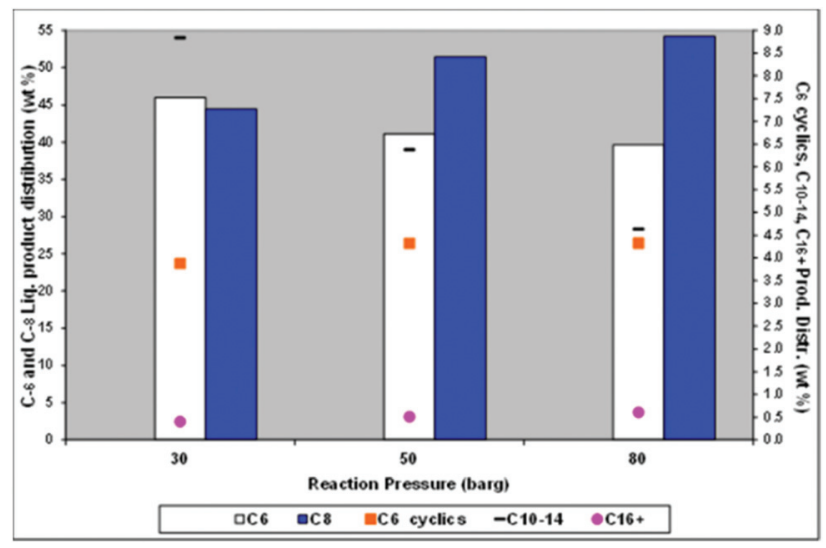

Fig. 3 Effect of reaction pressure on product selectivity.

In order to assess the performance of these bidentate PCNP based catalyst systems from a broader perspective, given their high $\mathrm{C}_{8}$ and total alpha selectivities, we wanted to probe the structural ligand features with those of known PNP (8), PCCP (9), and PNNP (10) based catalyst systems under similar reaction conditions (see Table 2). Diphosphine 9 was chosen over the more flexible $\mathrm{Ph}_{2} \mathrm{PCH}_{2} \mathrm{CH}_{2} \mathrm{PPh}_{2}$ (dppe) given the known lower activity and $1-\mathrm{C}_{6} / \mathrm{C}_{8}$ selectivities. ${ }^{2 a}$ While the bidentate PCNP based catalysts consistently yielded lower $1-\mathrm{C}_{8}$ to $1-\mathrm{C}_{6}$ ratio's than the catalysts based on ligands 8-10, all four PCNP based systems exhibited considerably higher catalyst activities than the catalysts containing 8-10. In addition, the total $\alpha$-selectivity observed for the catalyst system containing ligand 2a was noticeably higher than that obtained using $\mathbf{8}$ and $\mathbf{9}$, mainly as a result of an improved $1-\mathrm{C}_{6}$ selectivity.

Given that the catalyst system containing ligand 2a yielded the most promising activity and selectivity results amongst these PCNP systems, this system was used for further reaction condition optimisation, focussing on the effects of ethylene pressure and temperature.

\section{Effect of ethylene pressure}

The reaction pressure was varied from 30 to 80 barg at a constant temperature of $60{ }^{\circ} \mathrm{C}$ for the entire reaction period. Increasing the ethylene pressure from 30 to 50 barg resulted in a $31 \%$ increase in catalytic activity, which was not unexpected as the ethylene concentration in $\mathrm{MCH}$ increased 1.7 fold from 3.12 to $5.22 \mathrm{~mol} \mathrm{~L}^{-1}$ over this pressure range (Table 3$)^{33}$ However at 80 barg, where the ethylene concentration is $8.09 \mathrm{~mol} \mathrm{~L}^{-1}$, a reduction in catalyst activity was observed which could be ascribed to a possible compositional change affecting the catalyst solubility. All other trends of decreasing $\mathrm{C}_{6}$, increasing $\mathrm{C}_{8}$ and total alpha, lower $\mathrm{C}_{10-14}$ and high $\mathrm{C}_{8}$ : $\mathrm{C}_{6}$ continue across the pressure range studied here.

Keeping known mechanistic and kinetic considerations in mind, ${ }^{34,35}$ the increase in pressure resulted in an expected increased $\mathrm{C}_{8}$ selectivity, accompanied by a decrease in $1-\mathrm{C}_{6}$ content within the $\mathrm{C}_{6}$ fraction due to the increase in $\mathrm{C}_{6}$ cyclics formation (Fig. 3). The increase in 1-octene and $\mathrm{C}_{6}$ cyclics with pressure is indicative of a strong ethylene concentration dependence on these fractions. ${ }^{35}$ The reduction in $\mathrm{C}_{10-14}$ products formation observed with increasing pressure can be ascribed to the reduced concentration of the primary $1-\mathrm{C}_{8}$ and $1-\mathrm{C}_{6}$ products present at higher ethylene concentrations, thereby resulting in an improved total $\alpha$-selectivity. Based on these findings, the effect of reaction temperature at $50 \mathrm{barg}$ ethylene was studied in more detail.

\section{Effect of reaction temperature}

The reaction temperature was varied from 45 to $80^{\circ} \mathrm{C}$ at a constant ethylene pressure (50 barg) over the entire reaction

Table 4 Effect of reaction temperature on catalyst activity and product selectivity (using 2a)

\begin{tabular}{|c|c|c|c|c|c|c|c|c|c|c|c|c|c|c|}
\hline \multirow[b]{2}{*}{ Temp. } & \multirow[b]{2}{*}[\mathrm{C}_{2}\mathrm{H}_{4}]{$\left(\mathrm{mol} \mathrm{L}^{-1}\right)$} & \multicolumn{10}{|c|}{ Liquid product selectivity (wt \%) } & \multirow[b]{2}{*}{$1 \mathrm{C}_{8}: 1 \mathrm{C}_{6}$} & \multirow[b]{2}{*}{ Act. } & \multirow[b]{2}{*}{ PE } \\
\hline & & $\mathrm{C}_{6}$ & $1-\mathrm{C}_{6}$ & $1-\mathrm{C}_{6} / \mathrm{C}_{6}$ & $\mathrm{C}_{6}$ cyclics & $\mathrm{C}_{8}$ & $1-\mathrm{C}_{8}$ & $1-\mathrm{C}_{8} / \mathrm{C}_{8}$ & $\mathrm{C}_{10-14}$ & $\mathrm{C}_{16+}$ & Total $\alpha$ & & & \\
\hline 60 & 5.22 & 41.1 & 36.7 & 89.3 & 4.3 & 51.4 & 51.0 & 99.2 & 6.4 & 0.5 & 87.7 & 1.39 & 2.72 & 1.2 \\
\hline 80 & 4.24 & 59.5 & 56.8 & 95.5 & 2.7 & 34.4 & 34.1 & 99.1 & 5.7 & 0.2 & 91.0 & 0.60 & 3.11 & 0.6 \\
\hline
\end{tabular}

Conditions: $300 \mathrm{ml}$ Parr reactor, $2.5 \mu \mathrm{mol} \mathrm{Cr}(\mathrm{acac})_{3}$, MMAO-3A 960 eq., methylcyclohexane, 50 barg $\mathrm{C}_{2} \mathrm{H}_{4}$. Activity is given in ton product per g Cr per h. 


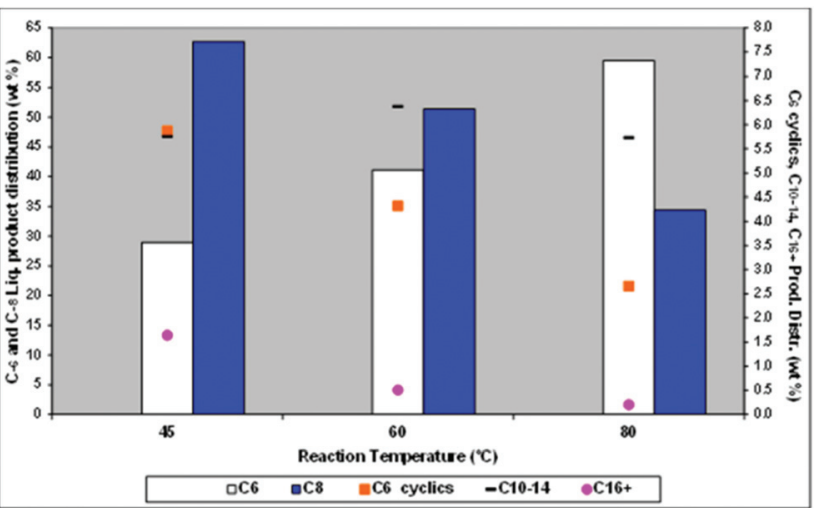

Fig. 4 Effect of reaction temperature on product selectivity at 50 barg

period. The effect of reaction temperature on catalyst activity and product selectivity at 50 barg ethylene pressure is illustrated by Table 4 and Fig. 4 . The catalyst activity improved significantly from 0.97 to 3.11 across the temperature range, despite the concomitant $33 \%$ reduction in ethylene concentration associated with the lower ethylene solubility at higher reaction temperature. This again suggests that the reaction temperature plays a dominant role in determining the optimal reaction rate. ${ }^{35}$

Lower reaction temperature resulted in an increase in overall $\mathrm{C}_{8}$ selectivity, including an increase in $1-\mathrm{C}_{8}$ and $\mathrm{C}_{6}$ cyclics, all of which is consistent with the benefit of higher ethylene concentrations at lower temperatures. The $\mathrm{C}_{10-14}$ selectivity remained constant across the temperature range evaluated, whilst an increase in both the $\mathrm{C}_{16+}$ and polyethylene selectivities are observed at lower reaction temperature.

\section{Conclusions}

In summary, four unsymmetrical bidentate PCNP ligands have been synthesised in a two-step reaction sequence. Catalytic testing, in conjunction with $\mathrm{Cr}^{\mathrm{III}}$ salts, revealed these ligands to generate active catalysts for ethylene tri-/tetramerisation. To further understand possible origins for this selectivity in terms of 1-hexene/1-octene formation, $\mathrm{Cr}^{0}$ complexes were prepared and their single crystal X-ray structures determined. The $\mathrm{P}-\mathrm{Cr}-$ $\mathrm{P}$ bite angle was found to increase, within this series, from $68.787(11)^{\circ}(\mathrm{Cr}-\mathrm{P}-\mathrm{N}-\mathrm{P})$ to $81.322(16) / 81.524(16)^{\circ}(\mathrm{Cr}-\mathrm{P}-\mathrm{N}-\mathrm{C}-$ $\mathrm{P})$ to $87.144(11)^{\circ}(\mathrm{Cr}-\mathrm{P}-\mathrm{C}-\mathrm{N}-\mathrm{C}-\mathrm{P})$. It should be noted that the $\mathrm{P}-\mathrm{Cr}-\mathrm{P}$ bite angle in 6 is $c a .4^{\circ}$ smaller than found in the $\mathrm{Cr}^{\mathrm{III}}$ compound $\mathrm{CrCl}_{3}(\mathbf{9})(\mathrm{thf})$ (thf $=$ tetrahydrofuran $)^{16}$ whilst the equivalent parameter in 7 is comparable with $\mathrm{CrCl}_{3}\left\{\mathrm{Cy}_{2} \mathrm{PCH}_{2} \mathrm{~N}\right.$ $\left.\left({ }^{\mathrm{i}} \mathrm{Pr}\right) \mathrm{CH}_{2} \mathrm{PCy}_{2}\right\}$ (thf) $\left[85.90(5)^{\circ}\right]$ previously reported by Le Floch and co-workers. ${ }^{10}$ A variety of bidentate PCNP ligands in combination with $\mathrm{Cr}^{\mathrm{III}}$ and activated with modified methyl aluminoxane were found to be highly active for ethylene tri- and tetramerisation. Optimisation of reaction conditions using ethylene pressure and temperature furnished further improvement of catalyst selectivity yielding a total $\alpha$-selectivity as high as $91 \%$.

\section{Experimental section}

\section{General methods}

The synthesis of ligands $\mathbf{1 a - d}, \mathbf{2 a - d}, \mathbf{3},{ }^{2 d, 30} \mathbf{4}$, and complexes 5-7, were carried out using standard Schlenk line techniques under an inert nitrogen atmosphere. $\mathrm{Ph}_{2} \mathrm{PCH}_{2} \mathrm{OH}$ was prepared according to a known procedure. ${ }^{36}\left[\mathrm{Cr}(\mathrm{CO})_{4}\left(\eta^{4}\right.\right.$-nbd $\left.)\right]$ (nbd $=$ norbornadiene) was prepared according to a known procedure. $^{37}$ All other chemicals, including reagent grade quality solvents, were obtained from commercial sources and used directly without further purification.

Infrared spectra were recorded as $\mathrm{KBr}$ pellets on a PerkinElmer Spectrum 100S (4000-250 $\mathrm{cm}^{-1}$ range) FourierTransform spectrometer. ${ }^{1} \mathrm{H}$ NMR spectra (400 or $500 \mathrm{MHz}$ ) were recorded on a Jeol-ECS-400 FT or Jeol-ECZ-R-500 spectrometer with chemical shifts $(\delta)$ in ppm to high frequency of $\mathrm{Si}$ $\left(\mathrm{CH}_{3}\right)_{4}$ and coupling constants $(J)$ in $\mathrm{Hz} .{ }^{31} \mathrm{P}\left\{{ }^{1} \mathrm{H}\right\}$ NMR (162 or $202 \mathrm{MHz}$ ) spectra were recorded on a Jeol-ECS-400 FT or JeolECZ-R-500 spectrometer with chemical shifts $(\delta)$ in ppm to high frequency of $85 \% \mathrm{H}_{3} \mathrm{PO}_{4}$. NMR spectra were measured in $\mathrm{CDCl}_{3}$ at $298 \mathrm{~K}$. Elemental analyses (PerkinElmer $2400 \mathrm{CHN}$ or Exeter Analytical, Inc. CE-440 Elemental Analyzers) were performed by the Loughborough University Analytical Service within the Department of Chemistry.

Preparation of $\mathbf{P h}_{\mathbf{2}} \mathbf{P C H}_{2}\{\mathbf{1 - N}(\mathbf{H}) \mathbf{N a p}\}$ (1a). Under nitrogen, a solution of 1-aminonaphthalene $(0.574 \mathrm{~g}, 4.01 \mathrm{mmol})$ and $\mathrm{Ph}_{2} \mathrm{PCH}_{2} \mathrm{OH}(1.088 \mathrm{~g}, 4.03 \mathrm{mmol})$ in freeze-thawed methanol (30 mL) was stirred for $24 \mathrm{~h}$. The solution was concentrated to approximately $10 \mathrm{~mL}$ under reduced pressure, and the resulting solid 1a filtered and dried in vacuo $(1.127 \mathrm{~g}, 82 \%) .{ }^{31} \mathrm{P}$ NMR: $\delta$-18.4. ${ }^{1} \mathrm{H}$ NMR: $\delta$ 7.9-6.7 (m, arom. H), $4.5(\mathrm{~s}, \mathrm{NH})$, $4.0 \mathrm{ppm}\left(\mathrm{d}, J=4.0 \mathrm{~Hz}, \mathrm{CH}_{2}\right)$. FT-IR: $\nu(\mathrm{NH}) 3378 \mathrm{~cm}^{-1}$. Found $\mathrm{C}, 80.71 ; \mathrm{H}, 5.69 ; \mathrm{N}, 4.17 . \mathrm{C}_{23} \mathrm{H}_{20} \mathrm{NP}$ requires $\mathrm{C}$, 80.92; $\mathrm{H}, 5.90$; $\mathrm{N}, 4.10 \%$.

Preparation of $\mathbf{P h}_{2} \mathbf{P C H}_{2}\{\mathbf{1}-\mathbf{N}(\mathbf{H})(4-\mathrm{Cl}) \mathrm{Nap}\}$ (1b). 1-Amino-4chloronaphthalene $(0.518 \mathrm{~g}, 2.86 \mathrm{mmol})$ and $\mathrm{Ph}_{2} \mathrm{PCH}_{2} \mathrm{OH}$ $(0.651 \mathrm{~g}, 2.86 \mathrm{mmol})$ in methanol $(20 \mathrm{~mL})$. The solution was stirred for $6 \mathrm{~d}$ and the solid product isolated (0.716 g, 67\%). ${ }^{31} \mathrm{P}$ NMR: $\delta$-18.7. ${ }^{1} \mathrm{H}$ NMR data: $\delta 8.1$ (d, $J=8.4 \mathrm{~Hz}$, arom. $\mathrm{H}$ ), 7.6-7.1 (m, arom. H), 6.6 (d, $J=8.0 \mathrm{~Hz}$, arom. H), 4.3 (s, NH), $3.9 \mathrm{ppm}\left(\mathrm{d}, J=4.0 \mathrm{~Hz}, \mathrm{CH}_{2}\right)$. FT-IR: $\nu(\mathrm{NH}) 3442 \mathrm{~cm}^{-1}$. Found $\mathrm{C}, 73.30 ; \mathrm{H}, 5.09 ; \mathrm{N}, 3.77 . \mathrm{C}_{23} \mathrm{H}_{19} \mathrm{NPCl}$ requires $\mathrm{C}, 73.50 ; \mathrm{H}$, $5.10 ; \mathrm{N}, 3.74 \%$.

Preparation of $\mathbf{P h}_{2} \mathbf{P C H}_{2}\{\mathbf{1 - N}(\mathbf{H})(4-\mathrm{Br}) \mathrm{Nap}\}$ (1c). 1-Amino-4bromonaphthalene $(1.548 \mathrm{~g}, 6.76 \mathrm{mmol})$ and $\mathrm{Ph}_{2} \mathrm{PCH}_{2} \mathrm{OH}$ $(1.507 \mathrm{~g}, 6.76 \mathrm{mmol})$ in methanol $(40 \mathrm{~mL})$. The solution was refluxed, under nitrogen, at $70-80{ }^{\circ} \mathrm{C}$ for $6 \mathrm{~d}$. The solid product was isolated $(1.720 \mathrm{~g}, 61 \%) .{ }^{31} \mathrm{P}$ NMR: $\delta-18.8 .{ }^{1} \mathrm{H}$ NMR data: $\delta 8.2$ (d, $J=8.8 \mathrm{~Hz}$, arom. H), 7.7-7.3 (m, arom. H), $6.7(\mathrm{~d}, J=8.4 \mathrm{~Hz}$, arom. H), $4.5(\mathrm{~s}, \mathrm{NH}), 4.0 \mathrm{ppm}(\mathrm{d}, J=4.0 \mathrm{~Hz}$, $\mathrm{CH}_{2}$ ). FT-IR: $\nu(\mathrm{NH}) 3443 \mathrm{~cm}^{-1}$. Found $\mathrm{C}, 65.44 ; \mathrm{H}, 4.57 ; \mathrm{N}$, 3.37. $\mathrm{C}_{23} \mathrm{H}_{19} \mathrm{NPBr}$ requires $\mathrm{C}, 65.73 ; \mathrm{H}, 4.56 ; \mathrm{N}, 3.33 \%$. 
Preparation of $\mathbf{P h}_{2} \mathbf{P C H}_{2}\{5-\mathrm{N}(\mathrm{H}) \mathrm{Quin}\} \quad$ (1d). 5Aminoquinoline $(0.964 \mathrm{~g}, 6.69 \mathrm{mmol})$ and $\mathrm{Ph}_{2} \mathrm{PCH}_{2} \mathrm{OH}$ $(1.490 \mathrm{~g}, 6.68 \mathrm{mmol})$ in methanol $(10 \mathrm{~mL})$. The solution was stirred for $11 \mathrm{~d}$. The solid product was isolated (1.753 g, 77\%). ${ }^{31}$ P NMR: $\delta$-18.5. ${ }^{1} \mathrm{H}$ NMR data: $\delta 8.8$ (m, arom. $\left.\mathrm{H}\right)$ 7.9-7.1 (m, arom. H), 6.7 (d, $J=7.6 \mathrm{~Hz}$, arom. H), 4.4 (s, NH), 3.9 ppm (d, $\left.J=4.4 \mathrm{~Hz}, \mathrm{CH}_{2}\right)$. FT-IR: $\nu(\mathrm{NH}) 3255 \mathrm{~cm}^{-1}$. Found C, 77.15; H, 5.64; N, 8.24. $\mathrm{C}_{22} \mathrm{H}_{19} \mathrm{~N}_{2} \mathrm{P}$ requires $\mathrm{C}, 77.18 ; \mathrm{H}, 5.59 ; \mathrm{N}, 8.18 \%$.

Preparation of $\mathbf{P h}_{2} \mathbf{P C H}_{2}\left\{\mathbf{1}-\mathbf{N}\left(\mathbf{P P h}_{2}\right) \mathbf{N a p}\right\}$ (2a). Under nitrogen, a small excess of lithium diisopropylamide $(0.70 \mathrm{~mL}$ of a 2.0 $\mathrm{M}$ solution in $\mathrm{THF} /$ heptane/ethylbenzene) was added to a solution of $1 \mathrm{a}(0.458 \mathrm{~g}, 1.27 \mathrm{mmol})$ in freeze-thawed THF $(25 \mathrm{~mL})$ at $-78^{\circ} \mathrm{C}$. The solution was stirred, at $-78^{\circ} \mathrm{C}$, for $1 \mathrm{~h}$ and then warmed to room temperature and stirred for a further $1 \mathrm{~h}$. $\mathrm{Ph}_{2} \mathrm{PCl}(0.23 \mathrm{~mL}, 1.3 \mathrm{mmol})$ was added dropwise at $-78{ }^{\circ} \mathrm{C}$ and the solution stirred, at room temperature, for $1.5 \mathrm{~h}$. The solvent was evaporated to dryness under reduced pressure and degassed hexane $(10 \mathrm{~mL})$ added. The solution was stirred at r.t. for $6 \mathrm{~h}$ and filtered under nitrogen. The solvent was evaporated to dryness under reduced pressure to give a yellow solid (0.615 g, 92\%). ${ }^{31} \mathrm{P}$ NMR: $\delta-21.7\left(\mathrm{PCH}_{2}\right)$, $67.0(\mathrm{PN}), J_{\mathrm{PP}}=8 \mathrm{~Hz} .{ }^{1} \mathrm{H}$ NMR data: $\delta 8.0-6.7$ (m, arom. H), 3.9-3.7 ppm (m, $\left.\mathrm{CH}_{2}\right)$. FAB MS: $m / z 340\left[M-\mathrm{PPh}_{2}\right]^{+}, 185$ $\left[\mathrm{PPh}_{2}\right]^{+}$. Despite numerous attempts, it was not possible to obtain an analytically pure sample of $\mathbf{2 a}$.

Preparation of $\mathbf{P h}_{2} \mathbf{P C H}\left\{\mathbf{1}-\mathbf{N}\left(\mathbf{P P h}_{2}\right)(4-\mathrm{Cl}) \mathbf{N a p}\right\}$ (2b). Lithium diisopropylamide $(0.63 \mathrm{~mL}$ of a $2.0 \mathrm{M}$ solution in $\mathrm{THF} /$ heptane/ethylbenzene), $\mathbf{1 b}(0.500 \mathrm{~g}, 1.14 \mathrm{mmol})$ and $\mathrm{Ph}_{2} \mathrm{PCl}$ (0.21 mL, $1.2 \mathrm{mmol})$ in THF $(15 \mathrm{~mL})$. The crude solid was purified by addition of degassed hexane $(20 \mathrm{~mL})$ and stirring at r.t. for $5 \mathrm{~h}$. The white solid was filtered under nitrogen and dried in vacuo (0.386 g, 60\%). ${ }^{31} \mathrm{P}$ NMR: $\delta-21.4\left(\mathrm{PCH}_{2}\right), 68.1(\mathrm{PN})$, $J_{\mathrm{PP}}=9 \mathrm{~Hz} .{ }^{1} \mathrm{H}$ NMR data: $\delta 8.1(\mathrm{~d}, J=8.4 \mathrm{~Hz}$, arom. $\mathrm{H}), 8.0(\mathrm{~d}$, $J=8.4 \mathrm{~Hz}$, arom. $\mathrm{H}), 7.5-6.9$ (m, arom. $\mathrm{H}), 3.9 \mathrm{ppm}\left(\mathrm{m}, \mathrm{CH}_{2}\right)$. FAB MS: $m / z 560[M]^{+}$. Despite numerous attempts, it was not possible to obtain an analytically pure sample of $2 \mathbf{b}$.

Preparation of $\mathbf{P h}_{2} \mathbf{P C H}_{2}\left\{\mathbf{1 - N}\left(\mathbf{P P h}_{2}\right)(4-\mathrm{Br}) \mathrm{Nap}\right\}$ (2c). Lithium diisopropylamide $(0.62 \mathrm{~mL}$ of a $2.0 \mathrm{M}$ solution in $\mathrm{THF} /$ heptane/ethylbenzene), 1c (0.504 g, $1.12 \mathrm{mmol})$ and $\mathrm{Ph}_{2} \mathrm{PCl}$ (0.20 mL, $1.1 \mathrm{mmol})$ in THF $(15 \mathrm{~mL})$. To the crude solid was added degassed diethyl ether $(20 \mathrm{~mL})$ and the solution stirred at room temperature for $5 \mathrm{~h}$. Under nitrogen, the white solid was filtered and dried in vacuo $(0.279 \mathrm{~g}, 41 \%) .{ }^{31} \mathrm{P}$ NMR: $\delta-21.4\left(\mathrm{PCH}_{2}\right), 68.2(\mathrm{PN}), J_{\mathrm{PP}}=9 \mathrm{~Hz} .{ }^{1} \mathrm{H}$ NMR data: $\delta 8.1(\mathrm{~d}, J=$ $8.4 \mathrm{~Hz}$, arom. H), $8.0(\mathrm{~d}, J=8.4 \mathrm{~Hz}$, arom. H), 7.6-6.8 (m, arom. $\mathrm{H}), 6.6$ (d, $J=8.4 \mathrm{~Hz}$, arom. $\mathrm{H}), 3.9 \mathrm{ppm}\left(\mathrm{m}, \mathrm{CH}_{2}\right) . \mathrm{FAB}$ MS: $m / z 605[M+\mathrm{H}]^{+}$. Despite numerous attempts, it was not possible to obtain an analytically pure sample of $2 \mathbf{c}$.

Preparation of $\mathbf{P h}_{2} \mathbf{P C H}_{2}\left\{\mathbf{5}-\mathbf{N}\left(\mathbf{P P h}_{2}\right)\right.$ Quin $\}$ (2d). Lithium diisopropylamide $(0.76 \mathrm{~mL}$ of a $2.0 \mathrm{M}$ solution in $\mathrm{THF} /$ heptane/ ethylbenzene), $1 \mathbf{d}(0.501 \mathrm{~g}, 1.38 \mathrm{mmol})$ and $\mathrm{Ph}_{2} \mathrm{PCl}(0.25 \mathrm{~mL}$, $1.4 \mathrm{mmol})$ in THF $(15 \mathrm{~mL})$. After evaporation to dryness, degassed diethyl ether $(20 \mathrm{~mL})$ was added and the solution stirred at r.t. for $5 \mathrm{~h}$. Under nitrogen, the solution was filtered and evaporated to dryness under reduced pressure to give a yellow solid (0.471 g, 65\%). ${ }^{31} \mathrm{P}$ NMR: $\delta-21.5\left(\mathrm{PCH}_{2}\right), 69.3$
$(\mathrm{PN}), J_{\mathrm{PP}}=8 \mathrm{~Hz} .{ }^{1} \mathrm{H}$ NMR data: $\delta 8.8(\mathrm{~m}$, arom. $\mathrm{H}), 8.3(\mathrm{~d}, J=$ $8.8 \mathrm{~Hz}$, arom. H), 7.8 (d, $J=8.4 \mathrm{~Hz}$, arom. H), 7.6-6.9 (m, arom. H), 6.7 (d, $J=7.6 \mathrm{~Hz}$, arom. $\mathrm{H}), 3.9 \mathrm{ppm}\left(\mathrm{m}, \mathrm{CH}_{2}\right) . \mathrm{FAB}$ MS: $m / z 527[M+\mathrm{H}]^{+}$. Despite numerous attempts, it was not possible to obtain an analytically pure sample of $\mathbf{2 d}$.

Preparation of 1-N( $\left.\mathbf{C H}_{2} \mathbf{P P h}_{2}\right)_{2} \mathbf{N a p}$ (4). A solution of 1-aminonaphthalene $(0.186 \mathrm{~g}, 1.30 \mathrm{mmol})$ and $\mathrm{Ph}_{2} \mathrm{PCH}_{2} \mathrm{OH}(0.584 \mathrm{~g}$, $2.59 \mathrm{mmol})$ in $\mathrm{MeOH}(10 \mathrm{~mL})$ was refluxed for $65 \mathrm{~h}$. The solution was concentrated to approx. $5 \mathrm{~mL}$ under reduced pressure and the white solid 4 filtered and dried in vacuo $(0.600 \mathrm{~g}$, 86\%). ${ }^{31} \mathrm{P}$ NMR: $\delta-28.0 .{ }^{1} \mathrm{H}$ NMR data: $\delta$ 7.9-7.0 (m, arom. $\left.\mathrm{H}\right)$, $4.3 \mathrm{ppm}\left(\mathrm{d}, J=2.4 \mathrm{~Hz}, \mathrm{CH}_{2}\right)$. Found $\mathrm{C}, 77.58 ; \mathrm{H}, 5.93 ; \mathrm{N}, 2.32$. $\mathrm{C}_{36} \mathrm{H}_{31} \mathrm{NP}_{2} \cdot \mathrm{CH}_{3} \mathrm{OH}$ requires $\mathrm{C}, 77.74 ; \mathrm{H}, 6.17 ; \mathrm{N}, 2.45 \%$.

Preparation of $\mathrm{Cr}(\mathrm{CO})_{4}(3)$ (5). Under $\mathrm{N}_{2}$, a solution of $\mathrm{Ph}_{2} \mathrm{PN}$ (1-Nap) $\mathrm{PPh}_{2}$ (3) $(0.118 \mathrm{~g}, 0.189 \mathrm{mmol})$ and $\mathrm{Cr}(\mathrm{CO})_{4}\left(\eta^{4}-\mathrm{nbd}\right)$ $(0.049 \mathrm{~g}, 0.19 \mathrm{mmol})$ in freeze-thawed THF $(20 \mathrm{~mL})$ was heated at $50{ }^{\circ} \mathrm{C}$ for $1 \mathrm{~h}$. Upon cooling, the solution was evaporated to dryness under reduced pressure $(0.075 \mathrm{~g}, 58 \%) .{ }^{31} \mathrm{P}$ NMR: $\delta$ 117.5. ${ }^{1} \mathrm{H}$ NMR data: $\delta$ 7.8-6.9 (m, arom. $\left.\mathrm{H}\right), 6.8(\mathrm{~d}, J=8.4$ $\mathrm{Hz}$, arom. H), $6.4 \mathrm{ppm}(\mathrm{t}, J=15 \mathrm{~Hz}$, arom. H). FT-IR: $\nu(\mathrm{CO})$ 2006, 1917, 1889, $1879 \mathrm{~cm}^{-1}$. Found C, 67.46; H, 4.47; N, 1.81. $\mathrm{C}_{38} \mathrm{H}_{27} \mathrm{NP}_{2} \mathrm{O}_{4} \mathrm{Cr}$ requires C, 67.55; H, 4.04; N, 2.07\%. FAB MS: $\mathrm{m} / \mathrm{z} 675[\mathrm{M}]^{+}$.

Preparation of $\mathrm{Cr}(\mathrm{CO})_{4}(2 \mathrm{a})$ (6). A solution of $2 \mathrm{a}(0.140 \mathrm{~g}$, $0.197 \mathrm{mmol})$ and $\mathrm{Cr}(\mathrm{CO})_{4}\left(\eta^{4}-\mathrm{nbd}\right)(0.051 \mathrm{~g}, 0.20 \mathrm{mmol})$ in freeze-thawed THF $(20 \mathrm{~mL})$ was heated, under $\mathrm{N}_{2}$, at $50{ }^{\circ} \mathrm{C}$ for 1 h. Upon cooling, the solvent was evaporated to dryness under reduced pressure $(0.096 \mathrm{~g}, 70 \%) .{ }^{31} \mathrm{P}$ NMR: $\delta \quad 67.9$ $\left(\mathrm{PCH}_{2}\right), 142.8(\mathrm{PN}), J_{\mathrm{PP}}=32 \mathrm{~Hz} .{ }^{1} \mathrm{H}$ NMR data: $\delta 7.8-6.6(\mathrm{~m}$, arom. H), 3.7 ppm (m, $\mathrm{CH}_{2}$ ). FT-IR: $\nu(\mathrm{CO})$ 2009, 1921, $1880 \mathrm{~cm}^{-1}$. Found $\mathrm{C}, 62.55 ; \mathrm{H}, \quad 5.12 ; \mathrm{N}, \quad 1.90$. $\mathrm{C}_{39} \mathrm{H}_{29} \mathrm{NP}_{2} \mathrm{O}_{4} \mathrm{Cr} \cdot 3 \mathrm{H}_{2} \mathrm{O}$ requires C, 62.99; H, 4.75; N, 1.88\%. FAB MS: $m / z 605[M-3 \mathrm{CO}]^{+}, 577[M-4 \mathrm{CO}]^{+}$.

Preparation of $\mathrm{Cr}(\mathrm{CO})_{4}(4) \quad$ (7). Ligand 4 (0.138 g, $0.230 \mathrm{mmol})$ and $\mathrm{Cr}(\mathrm{CO})_{4}\left(\eta^{4}\right.$-nbd $)(0.059 \mathrm{~g}, 0.23 \mathrm{mmol})$ in freeze-thawed THF $(20 \mathrm{~mL})$ was heated, under $\mathrm{N}_{2}$, at $50{ }^{\circ} \mathrm{C}$ for $1 \mathrm{~h}$. The solid product was isolated $(0.091 \mathrm{~g}, 56 \%) .{ }^{31} \mathrm{P}$ NMR: $\delta$ 41.0. ${ }^{1} \mathrm{H}$ NMR data: $\delta 7.8(\mathrm{~d}, J=8.0 \mathrm{~Hz}$, arom. $\mathrm{H}), 7.7(\mathrm{~d}, J=$ $8.0 \mathrm{~Hz}$, arom. H), $7.6(\mathrm{~d}, J=8.0 \mathrm{~Hz}$, arom. H), 7.5-7.0 (m, arom. H), 6.8 (t, $J=15 \mathrm{~Hz}$, arom. H), 6.6 (d, $8.8 \mathrm{~Hz}$, arom. H), 3.7 ppm (m, $\mathrm{CH}_{2}$ ). FT-IR: $\nu(\mathrm{CO}) 2007,1923,1877 \mathrm{~cm}^{-1}$. Found $\mathrm{C}, 68.24 ; \mathrm{H}, 4.79 ; \mathrm{N}, 2.10 . \mathrm{C}_{40} \mathrm{H}_{31} \mathrm{NP}_{2} \mathrm{O}_{4} \mathrm{Cr}$ requires $\mathrm{C}, 68.27 ; \mathrm{H}$, 4.45; N, 1.99\%. FAB MS: $m / z 591[M-4 \mathrm{CO}]^{+}$.

\section{Ethylene oligomerisation catalysis}

General catalytic techniques. The sensitivity of the catalyst species towards moisture and air required all procedures to be carried out under dry, inert conditions. This was accomplished using either a Braun glove box or using standard Schlenk line techniques. All catalyst preparations were carried out in oven treated glassware. Reagents and solvents were pre-dried using the techniques described below. Cr(III) acetylacetonate (97\% purity) was obtained from Sigma Aldrich and used without further purification whilst MMAO-3A ( $7 \mathrm{wt} \%$ in heptanes) was sourced from AkzoNobel. The Al to Cr ratio used was $960 \mathrm{eq}$. unless stated otherwise. Ethylene 3.5 (99.95\%) purity was 
obtained from Air Liquide or Linde AG. Methylcyclohexane (99\%) (MCH) and cyclohexane (99.5\%) were obtained from Sigma Aldrich and purified by percolation through neutral alumina. The catalyst concentration solutions employed in reactions were $2.5 \mu \mathrm{mol} \mathrm{Cr}$ and $2.75 \mu \mathrm{mol}$ ligand in $100 \mathrm{~mL}$ reaction solvent unless otherwise indicated.

Catalytic runs were carried out in $450 \mathrm{ml}$ Parr autoclaves (unless indicated otherwise) fitted with internal cooling coils, baffles and a gas entrainment stirrer. Ethylene uptake during catalysis was monitored by Danfoss Massflo (Type Mass 6000) flowmeter. Unless indicated otherwise, all reactions were conducted under standard conditions at $60^{\circ} \mathrm{C}$ and 45 barg ethylene pressure in a total volume of catalyst and solvent mixture of $100 \mathrm{~mL}$.

Catalytic reaction procedure. The reactor was heated to $120^{\circ} \mathrm{C}$ under vacuum for $1 \mathrm{~h}$ and then allowed to cool to room temperature under nitrogen purge. The pre-weighed reaction solvent was introduced to the reactor via syringe prior to heating the reactor to operating conditions. The ligand was dissolved in $25 \mathrm{~mL}$ of solvent and an aliquot combined with the chromium catalyst solution in a Schlenk vessel and stirred for $c a .5 \mathrm{~min}$ prior to addition of the activator. The resulting solution/suspension was transferred to the Parr reactor. The reactor was immediately charged with ethylene to the desired pressure and the reaction temperature was controlled by circulating water through the cooling coils during the catalytic run. Ethylene was fed on demand and thorough mixing was ensured by stirring at rates of 1200 RPM. The reaction was ter- minated after $160 \mathrm{~g}$ of ethylene was fed to the reactor by shutting off the ethylene feed followed by immediate cooling the reactor contents, using ice, to around $10{ }^{\circ} \mathrm{C}$. Following slow release of the excess ethylene from the autoclave, the reaction mixture was quenched with ethanol and $10 \% \mathrm{HCl}$. Nonane was added to the reaction mixture as external standard and the liquid phase was analysed by GC-FID. The remainder of the organic layer was filtered to isolate the polymeric material, which was dried in an oven at $100{ }^{\circ} \mathrm{C}$ overnight and weighed. Reaction selectivity data in Tables $2-4$ is reported in $\mathrm{wt} \%$ of the specific fraction in total liquid products normalised to $100 \%$. Total $\alpha$-selectivity is defined as the sum of the $1-\mathrm{C}_{6}$ and $1-\mathrm{C}_{8}$ fractions of total liquid products. Polyethylene (PE) reported is in $\mathrm{wt} \%$ of total product, activity is given in ton product per $\mathrm{g} \mathrm{Cr}$ per $\mathrm{h}$ and pressure $(\mathrm{P})$ is in barg.

\section{X-ray crystallographic studies}

Suitable crystals of 1a were obtained upon allowing a $\mathrm{MeOH}$ filtrate to stand for several days. Compounds 5, 6, and 7. $\mathrm{CH}_{2} \mathrm{Cl}_{2}$ were crystallised by slow diffusion of $\mathrm{MeOH}$ into a $\mathrm{CH}_{2} \mathrm{Cl}_{2}$ solution. Details of the data collection parameters and crystal data for $\mathbf{1 a}$ and 5,6 , and $7 \cdot \mathrm{CH}_{2} \mathrm{Cl}_{2}$ are presented in Table 5. All measurements were made on a Bruker AXS SMART $1000 \mathrm{CCD}$ area-detector diffractometer, at $150 \mathrm{~K}$, using graphite-monochromated $\mathrm{Mo}_{\mathrm{a}} \mathrm{K}_{\mathrm{a}}$ radiation and narrow frame exposures $\left(0.3^{\circ}\right)$ in $w^{38}$ Cell parameters were refined from the observed $(w)$ angles of all strong reflections in each data set. Intensities were corrected semi-empirically for absorption,

Table 5 Crystallographic data for $1 \mathrm{a}, 5,6$ and $7 \cdot \mathrm{CH}_{2} \mathrm{Cl}_{2}$

\begin{tabular}{|c|c|c|c|c|}
\hline Compound & $1 \mathbf{a}$ & 5 & 6 & $7 \cdot \mathrm{CH}_{2} \mathrm{Cl}_{2}$ \\
\hline Empirical formula & $\mathrm{C}_{23} \mathrm{H}_{20} \mathrm{NP}$ & $\mathrm{C}_{38} \mathrm{H}_{27} \mathrm{CrNO}_{4} \mathrm{P}_{2}$ & $\mathrm{C}_{39} \mathrm{H}_{29} \mathrm{CrNO}_{4} \mathrm{P}_{2}$ & $\mathrm{C}_{41} \mathrm{H}_{33} \mathrm{Cl}_{2} \mathrm{CrNO}_{4} \mathrm{P}_{2}$ \\
\hline Formula weight & 341.37 & 675.55 & 689.57 & 788.52 \\
\hline Crystal system & Monoclinic & Monoclinic & Monoclinic & Monoclinic \\
\hline Space group & $P 2_{1} / n$ & $P 2_{1} / n$ & $P 2_{1} / c$ & $P 2_{1} / c$ \\
\hline$a[\AA]$ & $17.5673(8)$ & $12.1106(4)$ & $22.7979(8)$ & $9.7908(3)$ \\
\hline$b[\AA]$ & $5.5130(3)$ & $19.6906(6)$ & $17.5266(6)$ & $17.7337(6)$ \\
\hline$c[\AA]$ & 18.5133(9) & $13.9703(4)$ & $16.9095(6)$ & $21.6935(7)$ \\
\hline$\alpha[0]$ & 90 & 90 & 90 & 90 \\
\hline$\beta[0]$ & $93.764(2)$ & $101.0381(4)$ & $96.9792(5)$ & $99.3296(5)$ \\
\hline$\gamma\left[^{\mathrm{o}}\right]$ & 90 & 90 & 90 & 90 \\
\hline Volume $\left[\AA^{3}\right]$ & $1789.12(15)$ & $3269.80(17)$ & $6706.5(4)$ & $3716.8(2)$ \\
\hline$Z$ & 4 & 4 & 8 & 4 \\
\hline$\Lambda$ & 0.71073 & 0.71073 & 0.71073 & 0.71073 \\
\hline$T[\mathrm{~K}]$ & $150(2)$ & $150(2)$ & $150(2)$ & $150(2)$ \\
\hline Density (calcd.) $\left[\mathrm{Mg} \mathrm{m}^{-3}\right]$ & 1.267 & 1.372 & 1.366 & 1.409 \\
\hline Absorption coeff. $\left[\mathrm{mm}^{-1}\right]$ & 0.158 & 0.490 & 0.479 & 0.581 \\
\hline Crystal habit and colour & Block, colourless & Block, yellow & Block, pale yellow & Block, pale yellow \\
\hline Crystal size $\left[\mathrm{mm}^{3}\right]$ & $0.50 \times 0.45 \times 0.21$ & $0.70 \times 0.43 \times 0.20$ & $0.47 \times 0.29 \times 0.22$ & $0.67 \times 0.41 \times 0.35$ \\
\hline$\theta$ Range $\left[{ }^{\circ}\right]$ & $2.32-28.79$ & $2.29-30.56$ & $2.33-29.50$ & $2.23-30.53$ \\
\hline Reflections collected & 15117 & 38624 & 78337 & 40840 \\
\hline Independent reflections & 4328 & 9988 & 20341 & 11309 \\
\hline$R_{\text {int }}$ & 0.018 & 0.021 & 0.039 & 0.023 \\
\hline Reflections with $F^{2}>2 \sigma\left(F^{2}\right)$ & 3567 & 8721 & 14758 & 9700 \\
\hline Number of parameters & 230 & 415 & 847 & 460 \\
\hline GOOF & 1.03 & 1.04 & 1.02 & 1.05 \\
\hline Final $R^{a}, R_{\mathrm{W}}{ }^{b}$ & $0.036,0.096$ & $0.031,0.087$ & $0.041,0.107$ & $0.039,0.109$ \\
\hline Largest diff peak \& hole [e̊̊] & $0.35,-0.21$ & $0.43,-0.50$ & $0.55,-0.64$ & $1.95,-1.42$ \\
\hline
\end{tabular}

${ }^{a} R=\sum|| F \mathrm{O}|-| F \mathrm{c}|| / \sum|F \mathrm{O}| \cdot{ }^{b} \mathrm{w} R 2=\left[\sum\left[\mathrm{w}\left(F \mathrm{O}^{2}-F \mathrm{c}^{2}\right)^{2}\right] / \sum\left[\mathrm{w}\left(F \mathrm{O}^{2}\right)^{2}\right]\right]^{1 / 2}$. 
based on symmetry-equivalent and repeated reflections. ${ }^{39}$ The structures were solved by direct methods (Patterson synthesis for 5 and 6) and refined on $F^{2}$ values for all unique data by full-matrix least-squares. ${ }^{40,41}$ All non-hydrogen atoms were refined anisotropically. Carbon-bound hydrogen atoms were constrained in a riding model with $U_{\text {eq }}$ set to $1.2 U_{\text {eq }}$ of the carrier atom. Compound 6 contains two very similar molecules in the asymmetric unit. In $7 \cdot \mathrm{CH}_{2} \mathrm{Cl}_{2}$ the solvent molecule of crystallisation was refined, with geometric and anisotropic displacement parameter restraints, over two sets of positions for all atoms with major component occupancy 67.8(14)\%. CCDC 2018019-2018022 $\uparrow$ contain the supplementary crystallographic data for this paper.

\section{Conflicts of interest}

There are no conflicts of interest to declare.

\section{Acknowledgements}

We thank the EPSRC, Sasol Technology (Pty) Ltd, and Loughborough University for studentships. The EPSRC Mass Spectrometry Service centre at Swansea are also acknowledged.

\section{Notes and references}

1 (a) O. L. Sydora, Organometallics, 2019, 38, 997-1010;

(b) T. Agapie, Coord. Chem. Rev., 2011, 255, 861-880; (c) P. W. N. M. van Leeuwen, N. D. Clément and M. J.-L. Tschan, Coord. Chem. Rev., 2011, 255, 1499-1517; (d) J. T. Dixon, M. J. Green, F. M. Hess and D. H. Morgan, J. Organomet. Chem., 2004, 689, 3641-3668.

2 (a) A. Bollmann, K. Blann, J. T. Dixon, F. M. Hess, E. Killian, H. Maumela, D. S. McGuinness, D. H. Morgan, A. Neveling, S. Otto, M. Overett, A. M. Z. Slawin, P. Wasserscheid and S. Kuhlmann, J. Am. Chem. Soc., 2004, 126, 14712-14713; (b) K. Blann, A. Bollmann, J. T. Dixon, F. M. Hess, E. Killian, H. Maumela, D. H. Morgan, A. Neveling, S. Otto and M. J. Overett, Chem. Commun., 2005, 620-621; (c) M. J. Overett, K. Blann, A. Bollmann, J. T. Dixon, F. Hess, E. Killian, H. Maumela, D. H. Morgan, A. Neveling and S. Otto, Chem. Commun., 2005, 622-624; (d) E. Killian, K. Blann, A. Bollmann, J. T. Dixon, S. Kuhlmann, M. C. Maumela, H. Maumela, D. H. Morgan, P. Nongodlwana, M. J. Overett, M. Pretorius, K. Höfener and P. Wasserscheid, J. Mol. Catal. A: Chem., 2007, 270, 214-218; (e) K. Blann, A. Bollmann, H. de Bod, J. T. Dixon, E. Killian, P. Nongodlwana, M. C. Maumela, H. Maumela, A. E. McConnell, D. H. Morgan, M. J. Overett, M. Prétorius, S. Kuhlmann and P. Wasserscheid, J. Catal., 2007, 249, 244-249.

3 (a) T. E. Stennett, T. W. Hey, L. T. Ball, S. R. Flynn, J. E. Radcliffe, C. L. McMullin, R. L. Wingad and D. F. Wass, ChemCatChem, 2013, 5, 2946-2954; (b) A. Carter, S. A. Cohen, N. A. Cooley, A. Murphy, J. Scutt and D. F. Wass, Chem. Commun., 2002, 858-859.

4 M. F. Haddow, J. Jaltai, M. Hanton, P. G. Pringle, L. E. Rush, H. A. Sparkes and C. H. Woodall, Dalton Trans., 2016, 45, 2294-2307.

5 (a) T. Agapie, M. W. Day, L. M. Henling, J. A. Labinger and J. E. Bercaw, Organometallics, 2006, 25, 2733-2742; (b) P. R. Elowe, C. McCann, P. G. Pringle, S. K. Spitzmesser and J. E. Bercaw, Organometallics, 2006, 25, 5255-5260.

6 M. Höhne, N. Peulecke, K. Konieczny, B. H. Müller and U. Rosenthal, ChemCatChem, 2017, 9, 2467-2472.

7 (a) X. Ji, L. Song, C. Zhang, J. Jiao and J. Zhang, Inorg. Chim. Acta, 2017, 466, 117-121; (b) Y. Zhou, H. Wu, S. Xu, X. Zhang, M. Shi and J. Zhang, Dalton Trans., 2015, 44, 9545-9550.

8 (a) D. S. McGuiness, P. Wasserscheid, D. H. Morgan and J. T. Dixon, Organometallics, 2005, 24, 552-556; (b) D. S. McGuiness, P. Wasserscheid, W. Keim, C. Hu, U. Englert, J. T. Dixon and C. Grove, Chem. Commun., 2003, 334-335.

9 Y. Shaikh, K. Albahily, M. Sutcliffe, V. Fomitcheva, S. Gambarotta, I. Korobkov and R. Duchateau, Angew. Chem., Int. Ed., 2012, 124, 1366-1369.

10 C. Klemps, E. Payet, L. Magna, L. Saussine, X. F. Le Goff and P. Le Floch, Chem. - Eur. J., 2009, 15, 8259-8268.

11 (a) S. D. Boelter, D. R. Davies, K. A. Milbrandt, D. R. Wilson, M. Wiltzius, M. S. Rosen and J. Klosin, Organometallics, 2020, 39, 967-975; (b) S. D. Boelter, D. R. Davies, P. Margl, K. A. Milbrandt, D. Mort, B. A. Vanchura II, D. R. Wilson, M. Wiltzius, M. S. Rosen and J. Klosin, Organometallics, 2020, 39, 976-987; (c) C. Zhang, L. Song, H. Wu, X. Ji, J. Jiao and J. Zhang, Dalton Trans., 2017, 46, 8399-8404.

12 L. Zhang, X. Meng, Y. Chen, C. Cao and T. Jiang, ChemCatChem, 2017, 9, 76-79.

13 C. Bariashir, C. Huang, G. A. Solan and W.-H. Sun, Coord. Chem. Rev., 2019, 385, 208-229.

14 B. R. Aluri, N. Peulecke, B. H. Müller, S. Peitz, A. Spannenberg, M. Hapke and U. Rosenthal, Organometallics, 2010, 29, 226-231.

15 L. E. Bowen, M. Charernsuk, T. W. Hey, C. L. McMullin, A. G. Orpen and D. F. Wass, Dalton Trans., 2010, 39, 560567.

16 M. J. Overett, K. Blann, A. Bollmann, R. de Villiers, J. T. Dixon, E. Killian, M. C. Maumela, H. Maumela, D. S. McGuiness, D. H. Morgan, A. Rucklidge and A. M. Z. Slawin, J. Mol. Catal. A: Chem., 2008, 283, 114-119.

17 S.-K. Kim, T.-J. Kim, J.-H. Chung, T.-K. Hahn, S.-S. Chae, H.-S. Lee, M. Cheong and S. O. Kang, Organometallics, 2010, 29, 5805-5811.

18 L. Zhang, W. Wei, F. Alam, Y. Chen and T. Jiang, Catal. Sci. Technol., 2017, 7, 5011-5018.

19 (a) S. M. Maley, D.-H. Kwon, N. Rollins, J. C. Stanley, O. L. Sydora, S. M. Bischof and D. H. Ess, Chem. Sci., 2020, 11, 9665-9674; (b) D.-H. Kwon, S. M. Maley, J. C. Stanley, O. L. Sydora, S. M. Bischof and D. H. Ess, ACS Catal., 2020, 
10, 9674-9683; (c) D.-H. Kwon, J. T. Fuller III, U. J. Kilgore, O. L. Sydora, S. M. Bischof and D. H. Ess, ACS Catal., 2018, 8, 1138-1142.

20 M. Gong, Z. Liu, Y. Li, Y. Ma, Q. Sun, J. Zhang and B. Liu, Organometallics, 2016, 35, 972-981.

21 N. Cloete, H. G. Visser, I. Engelbrecht, M. J. Overett, W. F. Gabrielli and A. Roodt, Inorg. Chem., 2013, 52, 22682270.

22 M. J. Overett, K. Blann, A. Bollmann, J. T. Dixon, D. Haasbroek, E. Killian, H. Maumela, D. S. McGuinness and D. H. Morgan, J. Am. Chem. Soc., 2005, 127, 1072310730.

23 N. A. Hirscher, J. A. Labinger and T. Agapie, Dalton Trans., 2019, 48, 40-44.

24 T. Gunasekara, J. Kim, A. Preston, D. K. Steelman, G. A. Medvedev, W. N. Delgass, O. L. Sydora, J. M. Caruthers and M. M. Abu-Omar, ACS Catal., 2018, 8, 6810-6819.

25 A. M. Lifschitz, N. A. Hirscher, H. B. Lee, J. A. Buss and T. Agapie, Organometallics, 2017, 36, 1640-1648.

26 G. M. Brown, M. R. J. Elsegood, A. J. Lake, N. M. SanchezBallester, M. B. Smith, T. S. Varley and K. Blann, Eur. J. Inorg. Chem., 2007, 1405-1414.

27 K. G. Gaw, M. B. Smith, J. B. Wright, A. M. Z. Slawin, S. J. Coles, M. B. Hursthouse and G. J. Tizzard, J. Organomet. Chem., 2012, 699, 39-47.

28 H. D. Fokwa, J. F. Vidlak, S. C. Weinberg, I. D. Duplessis, N. D. Schley and M. W. Johnson, Dalton Trans., 2020, 49, 9957-9960.
29 E. Payet, A. Auffrant, X. F. le Goff and P. Le Floch, J. Organomet. Chem., 2010, 695, 1499-1506.

30 H. T. Al-Masri, Z. Anorg. Allg. Chem., 2012, 638, 1012-1017.

31 L. M. Broomfield, C. Alonso-Moreno, E. Martin, A. Shafir, I. Posadas, V. Ceña and J. A. Castro-Osma, Dalton Trans., 2017, 46, 16113-16125.

32 L. E. Bowen, M. F. Haddow, A. G. Orpen and D. F. Wass, Dalton Trans., 2007, 1160-1168.

33 Calculations performed using Aspen Plus 12.1, 2008, PengRobinson Equation of State.

34 G. J. P. Britovsek, D. S. McGuinness, T. S. Wierenga and C. T. Young, ACS Catal., 2015, 5, 4152-4166.

35 R. Walsh, D. H. Morgan, A. Bollmann and J. T. Dixon, Appl. Catal., A, 2006, 306, 184-191.

36 H. Hellman, J. Bader, H. Birkner and O. Schumacher, Justus Liebigs Ann. Chem., 1962, 659, 49-56.

37 M. A. Bennett, L. Pratt and G. Wilkinson, J. Chem. Soc., 1961, 2037-2044.

38 SMART Program for Diffractometer Control, Bruker AXS Inc., Madison, WI, 2004.

39 (a) SAINT software for CCD diffractometers, Bruker AXS Inc., Madison, WI, 2004; (b) L. Krause, R. Herbst-Irmer, G. M. Sheldrick and D. J. Stalke, SADABS software, Appl. Crystallogr., 2015, 48, 3-10.

40 (a) G. M. Sheldrick, Acta Crystallogr., Sect. A: Found. Adv., 2015, A71, 3-8; (b) G. M. Sheldrick, Acta Crystallogr., Sect. A: Found. Adv., 2008, A64, 112-122.

41 G. M. Sheldrick, SHELXTL user manual, version 6.12, Bruker AXS Inc., Madison, WI, 2001. 